\title{
Does Technical or Strategic HRM Provide a Better Explanation of Organization Performance?
}

\author{
Chien-Chang Yang1, Carol Y. Y. Lin ${ }^{2}$ \\ ${ }^{1}$ Department of Human Resource, Far Eastern Memorial Hospital, Taiwan \\ ${ }^{2}$ Department of Business Administration, National Chengchi University, Taipei, Taiwan \\ Email: yang@mail.femh.org.tw, yehyunln@nccu.edu.tw
}

Received 21 February 2014; revised 23 April 2014; accepted 15 May 2014

Copyright (C) 2014 by authors and Scientific Research Publishing Inc.

This work is licensed under the Creative Commons Attribution International License (CC BY). http://creativecommons.org/licenses/by/4.0/

c) (i) Open Access

\begin{abstract}
This study is to examine the ability of technical HRM versus strategic HRM in predicting organizational performance in the health care industry. A postal survey was distributed to the HR managers of all the hospitals in Taiwan, with a response rate of $56 \%$. Hierarchical regression analyses were based on data from the 277 responding hospitals. From the result, we found that technical HRM is more important in explaining perceived organizational performance, and strategic HRM is better at predicting human capital accumulation. Technical HRM does not moderate the relationship between strategic HRM and perceived organizational performance, but it does moderate HR strategy and human capital accumulation.
\end{abstract}

\section{Keywords}

Human Resource Management, Technical HRM, Strategic HRM, Organizational Performance, Human Capital

\section{Introduction}

In today's knowledge economy, performance differences across organizations can be attributed to variations in each organization's resources and capabilities [1] [2]. The practitioners of human resource management (HRM) are endowed with the responsibility of developing organizational human resources and therefore play key roles in the resources and capabilities building.

Throughout the last few decades, researchers have examined the link between HRM and organizational-level performance, with an initial focus on the effects of the traditional or technical HRM and, in recent years, with an 
increasing emphasis on a strategy-oriented perspective [3]-[5]. As strategic HRM gains importance, HR research that examines technical and strategic HRM simultaneously adds value to the exploration of their complementary effects.

Technical HRM covers various traditional functions of HRM, such as recruiting and selection, training and development, performance appraisal, and compensation [6] [7]. Strategic HRM includes empowerment, high performance work systems, and career management that align with organizational goals [8]-[10]. This study is devoted to an examination of the different predicting powers of technical HRM and strategic HRM and their combined effect on organizational performance in the health care industry in Taiwan.

The rationale of conducting a study in the health care industry is that its organizations are staffed primarily by a highly knowledgeable workforce of medical professionals and accrue organizational values mainly from services provided by these professionals. Thus, examining HRM practices in hospitals should provide some insights for HRM in the knowledge economy. In addition, the context of our study - the health care industry in Taiwan - adds further value to this field of study, as have attested the importance of having HRM international perspective [7]. Specifically, this study attempts to answer the following questions:

1) Does HRM actually explain organizational performance?

2) Which has more influence on organizational performance: technical HRM or strategic HRM?

3) Does technical HRM moderate the relationship between strategic HRM and organizational performance?

\section{Literature and Hypothesis Development}

Resource-based theory stipulates that organizations differ in their unique bundles of resources and capabilities, which differentiate "successful" firms from "unsuccessful" firms [11]. Thus, a company's most important task is to maximize performance outcomes through the optimal deployment of existing resources and capabilities while at the same time continuing to develop its resource base in order to remain competitive in the future [11] [12]. Human resources are valuable intangible assets that generate capabilities and renew corporate knowledge. The human element has grown increasingly important in corporate structures because knowledge has become the most critical competitive asset an organization can possess. Therefore, a company's ability to generate specific or new knowledge is critical, and much of that ability resides in its human resources.

Although human resources may be mobile to some degree, some capabilities are based on firm-specific knowledge, and others are valuable only when integrated with additional individual capabilities and specific firm resources that may not be mobile [1]. This theoretical point of view suggests that an organization's pool of human resources can be "leveraged" to provide a competitive advantage [4] [13], and HRM is an important catalyst in accomplishing the task because effective HRM helps retain qualified human resources, develop the knowledge and skills of employees, and create firm value through the selection, development, and use of human capital [14].

In recent years, the focus of HR research in the last decade has shifted from a micro, technical perspective to a more macro, strategic perspective [5] [15] [16]. Technical HRM in this study is defined as traditional HRM activities, which includes recruiting, training, performance appraisal, compensation, employee relationships, and health and safety. Strategic HRM is defined as management practices that integrate organizational goals with HR functions in order to facilitate organizational performance in areas such as empowerment, high performance work systems, and career management. With decades of HRM research and training, the so-called HRM best practices have been developed. As a result, most HR managers are proficient in the delivery of traditional technical HRM activities [17]. However, with increasing competition, the conventional HRM that is practiced by almost every organization no longer provides a competitive advantage. HR departments need to design their activities strategically to help achieve organizational goals. In other words, with strategic HRM becoming an integral part of the HRM system, it is no longer enough for a company to focus solely on traditional technical HRM.

After strategic HRM came onto the scene, research investigating the relationship between general HRM and organizational performance proliferated. Although there is moderate yet consistent supports for the notion that HRM can have a positive impact on overall organizational performance, some studies indicate that HRM alone explains only a small portion of organizational performance. For instance, Bhattacharya et al., [18] reported that employees' skills, behaviors, and HRM flexibility together explain $8 \%$ of incremental variance in the financial performance of an organization. Collins et al., [9] found that network-building HR activities explained about 7\% 
of sales growth. These findings call for further studies from different perspectives, such as investigating HRM as a system rather than as a result of an individual HR activity, examining both technical HRM and strategic HRM, and exploring different performance criteria [5] [6] [19]. In response to such a call, this study attempts to investigate technical HRM as a system (examine technical and strategic HRM simultaneously), and to add human capital as another performance criterion because human capital accumulation is the end result of a sound HRM system.

Human capital is defined as all of the knowledge, skill, and experience of both employees and managers that can be transformed into competitiveness and wealth and is valuable, rare, and inimitable [16] [20] [21]. Scholars regard human capital as comprising three key elements: competitive ability, work attitude, and quickness in response [22]. Human capital can serve as an organizational profit lever [23] and is the greatest and most powerful asset an organization possesses in sustaining its competitive advantage. Since human capital is pivotal to an organization's lasting success, effective HRM practices within any organization must focus on accumulating and maintaining human capital. In other words, higher degree of human capital reflects the effectiveness of HRM.

HRM comprises many activities through which firms create human capital. Technical HRM, which has been increasingly regulated through stakeholder's expectations, includes recruiting, training, performance appraisal, compensation and benefits administration, employee relationships, and health and safety [3] [5]. Recruiting serves as the backbone for nearly all of an organization's HR activities and have a substantial influence over the quality and skills of new employees. When an employee's behavior departs significantly from the expectations placed on that employee - either negatively or positively — further actions need to be taken, such as training or transfer. Effective motivation for better performance through compensation and benefits administration should also be considered. In addition, high-performing organizations utilize performance appraisal results to guide training and development and to customize compensation programs for core employees. Employee relationships in a knowledge-intensive era and healthy and safe working environments in the health care industry are also of primary importance. Today's knowledge workers, unlike traditional blue-collar ones, request for work life quality in addition to their salary requirements. Therefore, building a pleasant, healthy, safe, and facilitating working environment has become an incentive that attracts and retains qualified employees.

Since we regard HRM as a system, comprising a series of HR activities, this study examines multiple rather than a single HRM activity. Previous research also confirmed that the HRM system of attracting, selecting, deploying, retaining, and transforming valuable human resources is gaining importance in the process of creating, re-creating, and accumulating human capital for organizational performance [24]. As technical HRM provides many valuable tools to manage, develop, and transform human resources into company value for ensuring organizational performance, the authors hypothesize that organization performance improves with better technical HRM.

\section{Hypothesis 1a: Better technical HRM enhances organizational performance.}

When employees perform well, they add value to the company; therefore, HR activities are seen as investments in human capital [25]. Lepak et al., [14] define human capital as the result of a company's making a deliberate investment by hiring certain individuals from a pool of potential employees. For effective recruiting and selection, some companies utilize various tests, including achievement tests, personality tests, and a series of interviews; other companies pay special attention to the potential of new recruits in key positions and implement a sound mentoring program. In short, HRM focuses on identifying workers with specific skills who can perform well, thus becoming human capital and enhance the organization's competitiveness.

Human capital theorists suggest that firms should invest in their employees to develop each employee's unique and firm-specific skills through extensive training initiatives; resource-based theorists also propose that core employee skills should be developed and maintained internally [14]. In a knowledge economy, internal training and development of firm-specific inimitable core competencies are of particular importance to creating human capital specificity.

Performance appraisal is also one of the key measures that enhances organizational human capital [24], since it provides employees with feedback on their performance and gives them direction in enhancing their competencies to meet the organization's goals [2]. In other words, developmental performance feedback nourishes firm-specific human capital and may be a potent source of sustained competitiveness.

An effective reward system is another key to inducing individuals to maintaining a lasting performance. An attractive compensation package must have both external competitiveness and internal equity, meaning the total package should be competitive in the marketplace while being perceived as a fair reward among peers within the 
organization [26]. In other words, competitive compensation is instrumental in retaining committed talents and is helpful in accumulating precious human capital. In addition to the four HRM practices above, employee relationships and health and safety also help organizations retain qualified employees and are particularly important for medical professionals in the knowledge-intensive, high-risk health care industry.

As stated above, organizations must continually enhance their human capital through recruitment, training, employee involvement, performance appraisal, compensation, and a stimulating work environment; therefore, the authors hypothesize that human capital accumulation is enhanced by better technical HRM.

Hypothesis 1b: Better technical HRM enhances human capital accumulation.

Currently, effective HRM cannot simply execute a standard set of HR policies and procedures. Rather, it requires questioning and understanding the relationships among choices in managing people, the strategies and goals of the organization, and the possibilities presented by the external environment —in other words, a "strategic HRM" mentality [2] [27]. The strategic view of HRM implies that an organization's human resources can be leveraged in order to give the organization an advantage in attaining enduring effectiveness. Therefore, designing and implementing a set of internally consistent HRM policies and practices may ensure that an organization's human resources contribute to the achievement of its business objectives. That is, HRM needs to be integrated with the overall business strategy and becomes firm-specific strategic HRM. Due to the social complexity and causal ambiguity inherent in strategic HRM, competitors can neither easily copy these practices nor can they readily replicate the unique pool of human capital that such practices help create [5]; thus, strategic HRM contributes to organizational competitiveness and performance. These strategic HR activities may include effective communication channels, team-based designs, flexible workforces, quality improvement practices, employee empowerment, and talent development [2] [5]. In summary, previous studies have indicated that strategic HRM contribute to the creation of a sustained competitive advantage for an organization [5] [28]. Therefore, the authors hypothesize that organizational performance is enhanced by strategic HRM that aligned with organizational business strategy.

Hypothesis 2a: Better strategic HRM enhances organizational performance.

Talent development is a key factor in building human capital. Talent development—or, to be more specific, career management - endeavors to match employees' long-term career goals with organizational goals through proper training in order to motivate and retain valuable employees [28]. Career management measures may include empowering, effective leading, developing, and promoting from within the organization [2] [28]. For strategic HRM to build and retain desired skills and knowledge in an organization's core employees, an analysis of the demand for and supply of competencies required by different positions has to be conducted. Good career management process facilitates high potential employees to acquire firm-specific competencies. Employee career planning, multi-skill development, management development, and employee assistance programs are some measures that nurture a qualified and committed employee for future internal promotion. Strategically, organizations generally implement training programs that produce non-transferable and firm-specific knowledge and skills not only to enhance competitiveness but also to create unique human capital through promotion from within.

For sustainable competitiveness, continuous talent development is a strategic measure that accelerates human capital accumulation. Organizations may use such strategic HRM to increase the values of human capital. Therefore, the authors hypothesize that human capital accumulation is enhanced through better strategic HRM.

Hypothesis 2b: Better strategic HRM enhances human capital accumulation

As mentioned in the introduction, this study would like to examine technical HRM and strategic HRM simultaneously to detect both their individual and combined influence on organizational performance and human capital accumulation. This implies an examination of their interactive and complementary effects, since the synergy argument is that the effects of the subsets are greater when they are implemented together.

Bae et al., [29] found that both people and HRM are emerging as critical sources for sustaining an organization's competitive advantage. Although previous studies discovered that sophisticated HR planning, recruitment and selection, and training are associated with both high labor productivity and organizational performance [6] [30], the relationship is not as strong as expected [2] [5] [9] [18] in particular, found no significant impact of technical HRM on firm performance. The indication of these findings is that technical HRM alone may not have good predictive power to explain organizational performance. Since strategic HRM has gained importance in recent years, research into the combined effect of technical HRM and strategic HRM on organizational performance is particularly appealing. 
Although strategic HRM is important in nurturing firm-specific knowledge and capabilities, yet without the support of a sound technical HRM - such as effective staffing and training - the effect of strategic HRM on organizational performance will be discounted. To improve organizational performance and enhance human capital accumulation, it is crucial that organizations implement both technical HRM and strategic HRM in such a way that they reinforce and complement each other as a coherent system, particularly technical HRM should be the foundation of strategic HRM. The authors therefore hypothesize that the relationship between strategic HRM practices, organizational performance, and human capital accumulation is moderated by technical HRM.

Hypothesis 3a: Technical HRM moderates the relationship between strategic HRM practices and organizational performance.

Hypothesis 3b: Technical HRM moderates the relationship between strategic HRM practices and human capital accumulation.

\section{Research Context}

In today's health care sector, patients are becoming well informed through multiple channels, such as the Internet, help lines, and personal means [31] [32]. Many patients capitalize on the available knowledge and are transformed from being passive care receivers to being active care consumers, which results in an increased demand for productivity and innovation and causes major challenges to health care providers [33].

The health care industry in Taiwan provides an appropriate context for studying this topic for the following reasons. Over the past few decades, the health care industry in Taiwan has prospered considerably. With more public hospitals becoming privatized and corporate-sponsored hospitals entering the field, the health care industry in Taiwan has become a free competition market that exerts great pressure on hospitals to sponsor more effective management systems. Since hospitals are service organizations, their intangible assets-including the quality of doctors, nurses, administrators, and service systems - are key factors that generally determine their overall success or failure. Consequently, since human resources are the main driver of these intangible assets, HRM plays a pivotal role in a hospital's ability to remain competitive in the market.

\section{Methods}

\subsection{Sample and Collection}

A questionnaire was used to collect data for our field of interest. The questionnaire was distributed to the HR managers of all 493 hospitals in Taiwan, with a response rate of $56 \%$ (277 responding hospitals). Among them, $26 \%$ have less than 400 employees; $16 \%$ have 401 to 800 employees; $26 \%$ have 801 to 1200 employees; $17 \%$ have 1201 to 1600 employees; and the remaining $15 \%$ have over 1600 employees. About $17 \%$ of the hospitals have been operating for less than 10 years, $41 \%$ been operating between 10 and 30 years, and the remaining $42 \%$ have been operating for over 30 years.

\subsection{Measurement}

The survey items were formulated from literature reviews and informal field interviews with HR professionals in hospitals, which were then reviewed by independent HR managers and a college HR lecturer with over 20 years of HR experience in a hospital. Since this is an organizational-level study, the questions were answered by HR managers and represented the perspective of the hospitals. The respondents were asked to indicate how much they agreed with each statement using a scale from 1 to 5 ( 1 = Do not agree at all, $5=$ Highly agree $)$. Refer to the appendix for the question items. For organizational performance, we adopted a multi-faceted and perceptual measures, In a study of nursing homes in Canada, Rondeau et al., [27] found that the use of perceptual measures is frequently the only available assessment for comparative purposes across a large sample of organizations. They used subjective organizational effectiveness measures to examine the relationship between HRM practices and organizational performance with three categories of dependent variables: employee outcomes, customer/client outcomes, and facility performance outcomes. Since public statistics of hospital performance in Taiwan are lacking and most hospitals regard their objective performances, such as return on investment, as confidential, we followed [27] and designed five perceptual organizational performance items that cover overall employee satisfaction and turnover rate (employee outcomes), patient loyalty (customer/client outcomes), and quality of medical service and management effectiveness (facility performance outcomes). In the current study, 
another performance criterion is human capital accumulation, the degree of human capital obtained by securing four items: the best human resources in the industry, employees who are experts in their jobs, employees who are skillful in their jobs, and employees who continually acquire new job-related skills.

Roos et al., [2] maintained that technical HRM concentrates on being technically correct, whereas strategic HRM is seen as strategic and political. In this study, the effectiveness of technical HRM is the respondent's perception of how well technical HRM functions are performed. A total of twenty items were utilized, including recruitment, selection, training, performance appraisal, compensation administration, employee relationships, and health and safety. Ten question items represent the perceptions of strategic HRM effectiveness, which include developing communications, facilitating teamwork, involving strategic planning, matching workforce planning with development, effectively supporting functional departments, and implementing a career management program [5] [15]. The demographic information includes the type of hospital (medical center, regional hospital, or community hospital), the total number of employees, and the number of years the hospital has been in operation.

\section{Analysis and Results}

Before testing the proposed hypotheses, we first calculated the mean of the technical HRM items with the rationale that they are regarded as a set of the HRM system; separating them into several factors would have unnecessarily complicated this research. However, ten strategic HRM items were sent into factor analysis because the contents of strategic HRM are more company or industry specific and have not yet been institutionalized. Table 1 shows the factor loadings of the two extracted factors, which were named "HR strategy" and "career management." That is, in this study strategic HRM contains HR strategy and career management. Table 2 indicates the reliability, mean, standard deviation, and correlation coefficient of the factors investigated. The measurement reached good reliabilities, ranging from $r=0.84$ to $r=0.94$. On a scale of $1-5$, the mean scores disclose that responding hospitals rated their human capital accumulation the highest (3.86) and career management the lowest (3.22). The high correlations between the factors are understandable, since companies that invest more in technical HRM tend to acknowledge the importance of HR strategy and career management. The hierarchical regression analyses shown in Table 3 and Table 4 explain the predicting power of technical and strategic HRM as well as their interaction relating to perceived organizational performance and human capital accumulation.

\section{Table 1. Factor loadings of strategic HRM.}

\begin{tabular}{lll}
\hline Item description & Factor 1 & Factor 2 \\
\hline HR strategy $(\alpha=0.91)$ & & \\
- Our HR department participates in hospital-wide strategic planning. & $\mathbf{0 . 6 8 6}$ & 0.447 \\
- $\quad$ Our HR department supports other functional departments well. & $\mathbf{0 . 7 8 3}$ & 0.404 \\
- $\quad \mathbf{0 . 8 9 6}$ & 0.201 \\
- We hospital has a good team performance. & $\mathbf{0 . 8 1 6}$ & 0.327 \\
Career Management $(\alpha=0.91)$ & $\mathbf{0 . 6 6 9}$ & 0.509 \\
- We have good management development programs. & & \\
- We have a good employee assistance program. & 0.366 & $\mathbf{0 . 8 2 4}$ \\
- We have a good talent development system. & 0.350 & $\mathbf{0 . 7 1 7}$ \\
- We have good employee career planning and development. & 0.335 & $\mathbf{0 . 8 4 1}$ \\
- We have a good multi-skill development system. & 0.417 & $\mathbf{0 . 6 9 0}$ \\
\hline
\end{tabular}

Table 2. Reliability, mean, standard deviation, and correlation table.

\begin{tabular}{lccccccc}
\hline & Reliability & mean & S.D. & 1 & 2 & 3 & 4 \\
\hline 1. Technical HRM & $\alpha=0.94$ & 3.46 & 0.67 & 1 & & & 5 \\
2. HR strategy & $\alpha=0.91$ & 3.54 & 0.76 & $0.83^{* * *}$ & 1 & & \\
3. Career management & $\alpha=0.91$ & 3.22 & 0.74 & $0.78^{* * *}$ & $0.78^{* * *}$ & 1 & $0.73^{* * *}$ \\
4. P.organizational performance & $\alpha=0.84$ & 3.49 & 0.68 & $0.84^{* * *}$ & $0.78^{* * *}$ & 1 \\
5. Human capital accumulation & $\alpha=0.87$ & 3.86 & 0.80 & $0.58^{* * *}$ & $0.35^{* * *}$ & $0.54^{* * *}$ & $0.53^{* * *}$ \\
\hline
\end{tabular}

Remark: All the correlation coefficients are significant at the 0.001 level. 
Table 3. Regression table with perceived organizational performance as the criterion.

\begin{tabular}{|c|c|c|c|c|c|c|c|}
\hline $\begin{array}{l}\text { Model Standardized } \\
\text { beta Variables }\end{array}$ & Model 1 & Model 2 & Model 3 & Model 4 & Model 5 & Model 6 & Model 7 \\
\hline \multicolumn{8}{|l|}{ Control variables } \\
\hline Nature of hospital & 0.015 & -0.017 & -0.016 & -0.028 & -0.019 & -0.024 & -0.023 \\
\hline Total employee \# & $0.178^{* *}$ & -0.056 & -0.056 & -0.066 & $-0.075^{*}$ & $-0.078^{*}$ & $-0.070^{*}$ \\
\hline Tenure of hospital & 0.016 & $0.072^{*}$ & 0.036 & $0.083^{*}$ & $0.063^{*}$ & $0.081^{*}$ & $0.076^{*}$ \\
\hline $\begin{array}{c}\text { Main effect } \\
\text { Technical HRM }\end{array}$ & \multicolumn{6}{|c|}{ Main effect } & $0.747^{* * *}$ \\
\hline \multicolumn{8}{|l|}{ Strategic HRM } \\
\hline -HR strategy & & & $.803^{* * *}$ & $0.533^{* * *}$ & $0.292^{* * *}$ & $0.238^{* * *}$ & 0.551 \\
\hline -Career Mgmt. & & & & $0.363^{* * *}$ & & $0.171^{*}$ & 0.097 \\
\hline \multicolumn{8}{|l|}{ Interaction } \\
\hline HR str. $\times$ THRM & & & & & & & 0.211 \\
\hline Career $\times$ THRM & & & & & & & -0.647 \\
\hline $\mathrm{R}^{2}$ & 0.031 & 0.714 & 0.626 & 0.682 & 0.739 & 0.749 & 0.753 \\
\hline Adjusted $\mathrm{R}^{2}$ & 0.020 & 0.710 & 0.595 & 0.056 & 0.025 & 0.010 & 0.004 \\
\hline
\end{tabular}

Remark: HR str.—HR strategy, Career Mgmt.—Career management, THRM—technical HRM. ${ }^{*} \mathrm{p}<0.05,{ }^{* *} \mathrm{p}<0.01,{ }^{* * *} \mathrm{p}<0.001$.

Table 4. Regression table with human capital accumulation as the criterion.

\begin{tabular}{|c|c|c|c|c|c|c|c|}
\hline $\begin{array}{l}\text { Model Standardized } \\
\text { beta Variables }\end{array}$ & Model 1 & Model 2 & Model 3 & Model 4 & Model 5 & Model 6 & Model 7 \\
\hline $\begin{array}{l}\text { Control variables } \\
\text { Nature of hospital } \\
\text { Total employee \# } \\
\text { Tenure of hospital }\end{array}$ & $\begin{array}{c}0.046 \\
0.291^{* * *} \\
0.044\end{array}$ & $\begin{array}{l}0.020 \\
0.104^{*} \\
0.088^{*}\end{array}$ & $\begin{array}{l}0.019 \\
0.089 \\
0.061\end{array}$ & $\begin{array}{l}0.010 \\
0.081 \\
0.093^{*}\end{array}$ & $\begin{array}{l}0.017 \\
0.078 \\
0.077\end{array}$ & $\begin{array}{l}0.012 \\
0.075 \\
0.092^{*}\end{array}$ & $\begin{array}{l}0.021 \\
0.063 \\
0.097^{*}\end{array}$ \\
\hline $\begin{array}{c}\text { Main effect } \\
\text { Technical HRM } \\
\text { Strategic HRM } \\
\text {-HR strategy } \\
\text {-Career Mgmt. }\end{array}$ & & $0.687^{* * *}$ & $0.695^{* * *}$ & $\begin{array}{l}0.509^{* * *} \\
0.251^{* * *}\end{array}$ & $\begin{array}{l}0.361^{* * *} \\
0.396^{* * *}\end{array}$ & $\begin{array}{c}0.286^{* * *} \\
0.349^{* * *} \\
0.147^{*}\end{array}$ & $\begin{array}{c}-0.191 \\
-0.672 \\
0.653\end{array}$ \\
\hline $\begin{array}{c}\text { Interaction } \\
\text { HR str. } \times \text { THRM } \\
\text { Career } \times \text { THRM }\end{array}$ & & & & & & & $\begin{array}{l}1.779^{* *} \\
-0.799\end{array}$ \\
\hline $\begin{array}{c}\mathrm{R}^{2} \\
\text { Adjusted } \mathrm{R}^{2}\end{array}$ & $\begin{array}{l}0.081 \\
0.071\end{array}$ & $\begin{array}{l}0.520 \\
0.513\end{array}$ & $\begin{array}{l}0.527 \\
0.446\end{array}$ & $\begin{array}{l}0.554 \\
0.027\end{array}$ & $\begin{array}{l}0.566 \\
0.046\end{array}$ & $\begin{array}{l}0.570 \\
0.004\end{array}$ & $\begin{array}{l}0.604 \\
0.034\end{array}$ \\
\hline
\end{tabular}

${ }^{*} \mathrm{p}<0.05,{ }^{* *} \mathrm{p}<0.01,{ }^{* * *} \mathrm{p}<0.00$.

In Table 3, with perceived organizational performance as the criterion, Model 1 shows the effects of the three control variables, where $R^{2}=0.031$. Model 2 adds technical HRM to the equation and results in a significant increase to $R^{2}=0.714$, explaining the significant impact of technical HRM on perceived organizational performance. In order to compare the relative predicting power between technical HRM and strategic HRM, Model 3 adds HR strategy to Model 1 equation, where $R^{2}=0.626$. Model 4 adds career management to Model 3 , with a slight increase to $R^{2}=0.682$. $R^{2}$ comparison between Model 2 (control variables plus technical HRM) and Model 4 (control variables plus strategic HRM) shows that technical HRM has a stronger predicting power than strategic HRM in explaining perceived organizational performance. Model 5 indicates that when both technical HRM and HR strategy are in the equation, $R^{2}$ increases to $R^{2}=0.739$. Model 6 includes all the factors - technical HRM, HR strategy, and career management-in the equation, with a slight increase to $R^{2}=0.749$. Overall, technical HRM and strategic HRM together have a better predicting power in explaining perceived organizational performance. However, in Model 7, where $R^{2}=0.753$, adding two interaction terms to the equation cancels the main effects of strategic HRM.

In other words, only technical HRM maintains a significant main effect on the perceived organizational performance excluding two control variables. A possible explanation is the conflicting effects of technical HRM and strategic HRM in some hospitals, meaning that some hospitals high in technical HRM may be low in strategic HRM and vice versa. The general effects of control variables in the seven models also reveal an interesting phenomenon in that Model 1 shows that hospitals with more employees have higher perceived organizational 
performance scores; yet Models 5, 6, and 7 indicate that after adding HRM factors, having more employees has a negative effect. Apparently, taking various HR activities into consideration, hospitals that have fewer employees achieve better perceived organizational performance. A possible explanation is that HRM requires resources and that having more employees dilutes the available resources required for achieving better organizational performance. In addition, Models 2, 4, 5, 6, and 7 show that hospitals with longer tenure have higher perceived organizational performance scores - very likely due to the management learning curve effect.

In Table 4, with human capital accumulation as the criterion, Model 1 shows the effects of three control variables, where $R^{2}=0.081$. Model 2 adds technical HRM to the equation and results in a significant increase to $R^{2}$ $=0.520$. Again, in order to compare the relative predicting power between technical HRM and strategic HRM, Model 3 adds HR strategy to Model 1 equation, with $R^{2}=0.527$. Model 4 adds career management to Model 3, with a slight increase to $R^{2}=0.554$. A comparison of Model 2 (control variables plus technical HRM) and Model 4 (control variables plus strategic HRM) shows that with human capital accumulation as the criterion, strategic HRM is slightly more important than technical HRM. Model 5 indicates that when both technical HRM and HR strategy are in the equation, $R^{2}$ increases to $R^{2}=0.566$. Model 6 includes technical HRM, HR strategy, and career management, resulting in a further increase to $R^{2}=0.573$. Model 7, where $R^{2}=0.604$, shows that when adding two interaction terms, only the interaction of HR strategy and technical HRM have a significant effect on human capital accumulation other than tenure of hospital. Interestingly, all the main effects disappear; in other words, to enhance human capital accumulation, companies need to facilitate the joint implementation of HR strategy and technical HRM. In general, the effect of career management on human capital accumulation is not as strong as one would expect. For the general effects of control variables, Models 1 and 2 show that hospitals with more employees have a higher score of human capital. In addition, Models 2, 4, 6, and 7 also indicate that hospitals with longer tenure have higher scores in human capital accumulation.

To answer our first research question, if HRM actually explains organizational performance, the results of Table 3 and Table 4 indicate that both technical HRM and strategic HRM are significant in explaining organizational performance in terms of perceived overall performance and human capital accumulation. For this question, hypotheses $\mathrm{H} 1 \mathrm{a}, \mathrm{H} 1 \mathrm{~b}, \mathrm{H} 2 \mathrm{a}$, and $\mathrm{H} 2 \mathrm{~b}$ are accepted. For the second research question, whether technical HRM or strategic HRM has a greater influence on organizational performance, with perceived organizational performance as the criterion, technical HRM has a stronger predicting power than strategic HRM. However, with human capital accumulation as the criterion, strategic HRM is slightly more important than technical HRM. As for the third research question, whether or not technical HRM moderates the relationship between strategic HRM and organizational performance, there is no significant interaction effect with perceived organizational performance as the criterion, but with human capital accumulation as the criterion, the interaction of HR strategy and technical HRM exerts the most effect and cancels all the HRM main effects on human capital accumulation. In other words, technical HRM moderates the relationship between HR strategy and human capital accumulation. This means that in order for HR strategy to play an effective role in enhancing human capital, good technical HRM needs to be in place. As a result, hypothesis $\mathrm{H} 3 \mathrm{a}$ is rejected and $\mathrm{H} 3 \mathrm{~b}$ is partially accepted.

\subsection{Discussion and Implications}

As mentioned earlier, the main purpose of this research is to examine the relative power of technical HRM and strategic HRM in predicting organizational performance. Data analyses reveal that technical HRM has more influence on perceived organizational performance, whereas strategic HRM has more influence on human capital accumulation. The results partially agree with the findings of Huselid [28] in which respondents perceived their firms' technical HR activities as being more effective than their firms' strategic HR activities; the controversy will be discussed in the next paragraph. In this study, the changes of $R^{2}$ and Model 6 results in Table 3 and Table 4 make it very clear that the combined effects of technical HRM and strategic HRM is much more powerful than their individual effects. This result is similar to Minbaeva's [19] finding that HRM practices applied as a coherent system have a greater effect on organizational performance.

Three results found in this study require further elaboration: the effects of technical HRM, the interaction of technical and strategic HRM, and career management. Generally speaking, this study found that technical HRM is still very important, despite the fact that HR directors are increasingly emphasizing strategic HRM. In fact, technical HRM is both the foundation and the infrastructure that facilitates effective implementation of strategic HR policies and procedures. This result agrees with the support of universalistic HRM found by Delery et al., 
[15] that a set of core HRM practices (technical HRM in this study) has its universal influence. However, different from Huselid [28] findings that technical HRM has no significant impact on firm performance, the current study shows the importance of technical HRM in explaining perceptual organizational performance and human capital accumulation. This difference may be a result of a different performance measurement, since Huselid and associates used objective company financial performance and our study used perceptual performance variables. Although subjective, the performance variables of this study reflect employees' daily perceptions and encounters, such as "our hospital management is effective," and "our employees are skillful in their jobs." These prevailing perceptions affect employee morale and the retention of qualified human resources; thus, a study with subjective performance evaluation has a practical value because human beings are subjective and emotionally bound.

The limited-interaction effect of technical HRM and strategic HRM on organizational performance presents the most interesting finding in this research. The rationale of the interaction effect is a contingency concept for strategic HRM to have a significant effect on organizational performance; an organization needs to implement good technical HRM as well. Yet the result of Model 7 in Table 3 does not reflect the above contingency statement; instead, the finding of Model 6 explains that good technical HRM and strategic HRM combined facilitate better organizational performance. In other words, it is the additive implementation of both technical HRM and strategic HRM - and not the contingency effect - that best explains perceived organizational performance. However, the result of Model 7 in Table 4 supports the contingency effect. For HR strategy to maximize its effect on better human capital accumulation, good technical HRM needs to be in place. The first interaction finding in Model 7 of Table 3 explains that hospitals with better technical HRM do not necessarily have good strategic HRM as well and vice versa. However, as long as its technical HRM is strong, high perceived organizational performance can still be anticipated. The second interaction finding in Model 7 of Table 4 indicates that in order to enhance human capital, a hospital needs not only a strong HR strategy but also sound technical HRM.

Counter-intuitively, career management turns out to have little main effect and no interaction effect on human capital accumulation. A possible explanation is that in hospitals, the high entry barrier of medical technology constrains the influence of career management designed by the HR department. The lowest mean score of career management in Table 1 indicates that this is the weakest part of hospital HRM practices. The wide medical discipline gap hampers doctors' multiple skill development, and a majority of advanced medical training is carried out by senior doctors, medical schools, or medical associations. Career development conducted by hospital HR departments through various HR activities appears to exert little influence on career progression for the medical doctors, technicians, and nurses. This finding implies that the career management process is industry specific and should be carefully designed in order for hospitals to reap a return on their investments.

The following implications can be derived from the research findings. First, the impact of strategic HRM on human capital accumulation found in this study reflects today's fierce competition for talented people. Since obtaining valuable human capital has become the key to future competition, talent development and talent management can no longer be regarded as an operational issue; rather, it is a strategic matter that has to be carefully attended to, not only by HR managers, but also by top management team members and line managers.

Second, to achieve organizational performance, technical HRM and strategic HRM need to be pursued in a complementary manner. As mentioned earlier, nowadays companies have become more proficient in technical HRM capabilities, a ceiling effect may begin to constrain the ability of companies to gain competitive advantage through continued improvements in technical HRM activities. Consequently, effective strategic HRM needs to be complementarily employed. The interaction effect found in this study reveals that a majority of the surveyed hospitals failed to implement both good technical HRM and strategic HRM. Very likely, resource constraints prevented the hospitals from implementing both of them in a profound manner. Yet as business competition becomes fiercer, efforts should be directed toward building sound HRM systems that include both technical and strategic HR issues - particularly facilitating the strategic role of the HR department in effectively developing human capital.

This study empirically tests the relative importance of technical and strategic HRM in enhancing organizational performance and human capital accumulation, and it provides another dimension in which researchers can examine the effect of HRM systems. The research results also uncover a clear path of what to emphasize in achieving different performance goals - perceived organizational performance or human capital accumulation. Particularly, HR strategy, in facilitating human capital accumulation, should prompt organizations to re-examine the responsibility of the HR department. 


\subsection{Limitations and Future Research}

Several limitations suggest that any conclusions drawn from this research should be viewed with some caution. First, our measures of organizational performance reflect the subjective assessments of HR managers. Although a number of scholars claim that perceptual assessments of performance are strongly associated with more objective assessments, they are still subject to the inherent biases and perceptual distortions of the assessors. Second, this set of data is collected from a single organizational source; common method bias may be a concern. It is a common limitation of similar studies mainly because there is only one HR manager for organizations of this scale (about $70 \%$ of the surveyed hospitals have less than 1200 employees). General HR staff would not be able to answer strategic HRM survey items. Nevertheless, we have adjusted for this bias both by designing multifaceted organizational performance items and by expanding the number of organizational respondents suggested by literature [27]. With a good representational $56 \%$ response rate of all hospitals in Taiwan, this data set is valuable in revealing the HRM practices in a knowledge-intense setting. Third, it should be noted that there are real differences between what managers say they do and what the organization actually does. This is also a common limitation that social science studies encounter.

Future studies may benefit from collecting objective organizational performance data in other industries where public ROA and/or ROI can be obtained to further test the relationships hypothesized in this study. A future longitudinal study may also be conducted to examine the time lag effect of human capital accumulation and organizational performance. In addition, a cross-cultural comparison will definitely benefit this field of study.

\subsection{Conclusion}

In a hypercompetitive era, success in business is no longer achieved through healthy financial statements or by having the most innovative product; it is achieved through people. Attracting valuable human resources has become a global competition. Companies should try to sustain their competitive position by obtaining, developing, utilizing, and retaining valuable employees through various HRM practices. HRM effectiveness, including the delivery of high quality technical HRM and strategic HRM in a complementary manner, will result in positive firm-level outcomes.

\section{References}

[1] Hitt, M.A., Bierman, L., Shimizu, K. and Kochhar, R. (2001) Direct and Moderating Effects of Human Capital on Strategy and Performance in Professional Service Firms: A Resource-Based Perspective. Academy of Management Journal, 44, 13-28. http://dx.doi.org/10.2307/3069334

[2] Roos, G., Fernstrom, L. and Pike, S. (2004) Human Resource Management and Business Performance Measurement. Measuring Business Excellence, 8, 28-37. http://dx.doi.org/10.1108/13683040410524711

[3] Schuler, R.S. (1992) Strategic Human Resource Management: Linking People with the Needs of Business. Organizational Dynamics, 21, 18-32. http://dx.doi.org/10.1016/0090-2616(92)90083-Y

[4] Wright, P.M. and McMahan, G.C. (1992) Theoretical Perspectives for Strategic Human Resource Management. Journal of Management, 18, 295-320. http://dx.doi.org/10.1177/014920639201800205

[5] Huselid, M.A., Jackson, S.E. and Schuler, R.S. (1997) Technical and Strategic Human Resource Management Effectiveness as Determinants of Organizational Performance. Academy of Management Journal, 40, 171-188. http://dx.doi.org/10.2307/257025

[6] Youndt, M.A., Snell, S.A., Dean, J.W. and Lepak, D.P. (1996) Human Resource Management, Manufacturing Strategy, and Firm Performance. Academy of Management Journal, 39, 836-866. http://dx.doi.org/10.2307/256714

[7] Schuler, R.S. and Jackson, S.E. (2005) A Quarter-Century Review of Human Resource Management in the US: The Growth in Importance of the International Perspective. Management Revue, 16, 1-25.

[8] Becker, B.A. and Huselid, M.A. (1998) High Performance Work Systems and Firm Performance: A Synthesis of Research and Managerial Applications. Research in Personnel and Human Resources Management, 16, 53-101.

[9] Collins, C.J. and Clark, K.D. (2003) Strategic Human Resource Practices, Top Management Team Social Networks, and Firm Performance: The Role of Human Resource Practices in Creating Organizational Competitive Advantage. Academy of Management Journal, 46, 740-751. http://dx.doi.org/10.2307/30040665

[10] Chan, L.L., Shaffer, M.A. and Snape, E. (2004) In Search of Sustained Competitive Advantage: The Impact of Organizational Culture, Competitive Strategy and Human Resource Management Practices on Firm Performance. International Journal of Human Resource Management, 15, 17-35. http://dx.doi.org/10.1080/0958519032000157320 
[11] Teece, D.J., Pisano, G. and Shuen, A. (1997) Dynamic Capabilities and Strategic Management. Strategic Management Journal, 18, 509-533. http://dx.doi.org/10.1002/(SICI)1097-0266(199708)18:7<509::AID-SMJ882>3.0.CO;2-Z

[12] Grant, R. (1996) Prospering in Dynamically Competitive Environments: Organizational Capability as Knowledge Integration. Organization Science, 7, 375-88. http://dx.doi.org/10.1287/orsc.7.4.375

[13] Barney, J.B. (1991) Firm Resources and Sustained Competitive Advantage. Journal of Management, 17, 99-120. http://dx.doi.org/10.1177/014920639101700108

[14] Lepak, D.P. and Snell, S.A. (1999) The Human Resource Architecture: Toward a Theory of Human Capital Allocation and Development. Academy of Management Review, 24, 31-48.

[15] Delery, J.E. and Doty, D.H. (1996) Modes of Theorizing in Strategic Human Resource Management: Test of Universalistic, Contingency, and Configurational Performance Predictions. Academy of Management Journal, 39, 802-835. http://dx.doi.org/10.2307/256713

[16] Youndt, M.A. and Snell, S.A. (2004) Human Resource Configurations, Intellectual Capital, and Organizational Performance. Journal of Managerial Issues, 16, 337-360.

[17] Sheehan, C. (2005) A Model for HRM Strategic Integration. Personnel Review, 34, 192-209. http://dx.doi.org/10.1108/00483480510579420

[18] Bhattacharya, M., Gibson, D.E. and Doty, D.H. (2005) The Effects of Flexibility in Employee Skills, Employee Behaviors, and Human Resource Practices on Firm Performance. Journal of Management, 31, 622-641. http://dx.doi.org/10.1177/0149206304272347

[19] Minbaeva, D. (2005) HRM Practices and MNC Knowledge Transfer. Personnel Review, 34, 125-144. http://dx.doi.org/10.1108/00483480510571914

[20] Bontis, N. (1998) Intellectual Capital: An Exploratory Study that Develops Measures and Models. Management Decision, 36, 63-76. http://dx.doi.org/10.1108/00251749810204142

[21] Davis, P. (2006) Beyond Human Resource Management in Co-Operatives. Cross Cultural Management, 13, 69-95. http://dx.doi.org/10.1108/13527600610643493

[22] Roos, J., Roos, G., Dragonetti, N.C. and Edvinsson, L. (1997) Intellectual Capital: Navigating in the New Business Landscape. Basingtoke, Macmillan.

[23] Bontis, N. and Fitz-enz, J. (2002) Intellectual Capital ROI: A Causal Map of Human Capital Antecedents and Con sequents. Journal of Intellectual Capital, 3, 223-247. http://dx.doi.org/10.1108/13527600610643493

[24] Rutherford, M.W., Buller, P.F. and McMullen, P.R. (2003) Human Resource Management Problems over the Life Cycle of Small to Medium-Sized Firms. Human Resource Management, 42, 321-341. http://dx.doi.org/10.1002/hrm.10093

[25] Snell, S.A. and Dean, J.W. (1992) Integrated Manufacturing and Human Resource Management: A Human Capital Perspective. Academy of Management Journal, 35, 467-504. http://dx.doi.org/10.2307/256484

[26] Terpstra, D.E. and Honoree, A.L. (2003) The Relative Importance of External, Internal, Individual and Procedural Equity to Pay Satisfaction. Compensation and Benefits Review, 35, 67-80. http://dx.doi.org/10.1177/0886368703259005

[27] Rondeau, K.V. and Wagar, T.H. (2001) Impact of Human Resource Management Practices on Nursing Home Performance. Health Services Management Research, 14, 192-202. http://dx.doi.org/10.1258/0951484011912690

[28] Huselid, M.A. (1995) The Impact of Human Resource Management Practices on Turnover, Productivity, and Corporate Financial Performance. Academy of Management Journal, 38, 635-672. http://dx.doi.org/10.2307/256741

[29] Bae, J. and Lawler J.J. (2000) Organizational and HRM Strategies in Korea: Impact on Firm Performance in an Emerging Economy. Academy of Management Journal, 43, 502-517. http://dx.doi.org/10.2307/1556407

[30] Koch, M. and McGrath, R. (1996) Improving Labor Productivity: Human Resource Management Policies Do Matter. Strategic Management Journal, 17, 335-354. http://dx.doi.org/10.1002/(SICI)1097-0266(199605)17:5<335::AID-SMJ814>3.0.CO;2-R

[31] Morath, J. (2003) Changing the Healthcare Culture: The Consumer as Part of the System and Care Implement Strategies Built around Improving the Quality of Care and with an Evidence-Based Perspective of the Patient at the Center. Frontiers of Health Services Management, 19, 17-28.

[32] Scott, C.M. (2003) The Impact of the Consumer on Healthcare Delivery. Frontiers of Health Services Management, 19, 41-44.

[33] Herzlinger, R.E. (2002) Let's Put Consumers in Charge of Health Care. Harvard Business Review, 80, 44-55. 